\title{
RENCANA PENGELOLAAN PARTISIPATIF OBJEK GEOWISATA TEBING KOJA (STUDI KASUS: TEBING KOJA, DESA CIKUYA, KECAMATAN SOLEAR, KABUPATEN TANGERANG)
}

\author{
Sandra Soraya ${ }^{1)}$, Parino Rahardjo ${ }^{2)}$, Suryono Herlambang ${ }^{3)}$ \\ 1)Program Studi S1 PWK, Fakultas Teknik, Universitas Tarumanagara, sandraasoraya@gmail.com \\ 2) Program Studi S1 PWK, Fakultas Teknik, Universitas Tarumanagara, parinor19@gmail.com \\ 3) Program Studi S1 PWK, Fakultas Teknik, Universitas Tarumanagara, s.herlambang@gmail.com
}

Masuk: 10-08-2020, revisi: 07-09-2020, diterima untuk diterbitkan: 25-09-2020

\begin{abstract}
Abstrak
Objek wisata Tebing Koja memiliki daya tarik geowisata yang memikat wisatawan dan dapat memberikan rasa ingin tahu seseorang karena memiliki sebutan lain yaitu "Kandang Godzilla" dan letaknya berada di dalam perdesaan di Kabupaten Tangerang. Tebing Koja memiliki keunikan tersendiri, yaitu bentuk tebingnya yang menjulang tinggi secara terpisah seperti bentukkan pada zaman purba akibat dari hasil penambangan pasir/kapur yang dilakukan sebelum dibukanya untuk umum pariwisata ini. Tebing Koja menjadi sangat penting yang dapat menjadi penunjang ekonomi bagi masyarakat sekitar yang ingin mengembangkan objek wisata tersebut. Namun, partisipasi yang dilakukan oleh masyarakat atau kelompok masyarakat hanyalah mereka yang tinggal di sekitaran Tebing Koja. Masyarakat lain maupun masyarakat Desa Cikuya masih acuh tak acuh terhadap adanya objek wisata Tebing Koja yang dapat memberikan keuntungan dalam perekonomian mereka. Berdasarkan uraian tersebut maka peneliti bertujuan untuk mendeskripsikan bentuk partisipatif pada masyarakat atau kelompok dalam pengelolaan objek wisata Tebing Koja di Desa Cikuya agar menjadikan pariwisata berkelanjutan. Konsep pariwisata berkelanjutan diterapkan dalam perencanaan pengelolaannya agar selalu berkesinambungan di kemudian hari dengan memanfaatkan sumber daya yang ada. Penelitian ini menggunakan pendekatan kualitatif dengan metode deskriptif analisis yang menggunakan pendeksripsian partisipatif dalam pengelolaan objek wisata Tebing Koja. Peneliti menggunakan berbagai sumber data untuk diteliti, menguraikan dan menjelaskannya secara komperhensif dari berbagai aspek dari individu, kelompok, organisasi, peristiwa secara sistematik. Teknik pengumpulan data yang digunakan peneliti adalah observasi, in-depth interview, dan dokumentasi. Hasil penelitian ini menunjukkan peran masyarakat dalam pengelolaan objek wisata, konsep pengelolaan berbasis masyarakat atau Community Based Tourism (CBT) dan faktor-faktor penghambatnya.
\end{abstract}

Kata Kunci: Pengelolaan Pariwisata Berbasis Masyarakat; Kemitraan Berbagai Pelaku; Perencanaan Wisata Geopark; Taman Tebing Koja

\begin{abstract}
Tebing Koja tourism object has a geotourism attraction that attracts tourists and can give someone's curiosity because it has another designation that is "Cage Godzilla" and is located in the countryside in Tangerang Regency. Tebing Koja has its own uniqueness, namely the form of the towering cliffs separately as if bent on ancient times as a result of the results of sand / lime mining which was carried out before it was opened to the public for this tourism. Tebing Koja becomes very important that can be an economic support for the surrounding community who want to develop these attractions. However, participation by the community or community groups is only those who live around Tebing Koja. Other communities and the community of Cikuya Village are still indifferent to the existence of the Tebing Koja tourism object that can provide benefits in their economy. Based on the description, the researcher aims to describe the participatory form in the community or group in managing the Tebing Koja tourism object in Cikuya Village to make tourism sustainable. The concept of sustainable tourism is applied in planning for management so that it is always sustainable in the future by utilizing existing resources. This study uses a
\end{abstract}


qualitative approach with a descriptive analysis method that uses participatory description in the management of the Tebing Koja tourism object. Researchers use various data sources to be studied, describe and explain comprehensively from various aspects of individuals, groups, organizations, events systematically. Data collection techniques used by researchers are observation, in-depth interviews, and documentation. The results of this study show the role of the community in managing tourist objects, the concept of community-based management or Community Based Tourism (CBT) and the inhibiting factors.

\section{Keywords: Community Based Tourism (CBT) Management; Stakeholders Partnership; Geopark Tourism Planning; Koja Cliff Park}

\section{PENDAHULUAN}

\section{Latar Belakang}

Pengembangan geowisata ditujukan untuk mendukung pembangunan pariwisata berbasis masyarakat. Pembangunan kepariwisataan tidak bisa lepas dari hak masyarakat lokal di destinasi wisata. Sumber daya dan keunikan komunitas lokal merupakan unsur penggerak utama kegiatan wisata itu sendiri. Hal tersebut mengisyaratkan bahwa pariwisata secara ideal merupakan kegiatan berbasis komunitas kemasyarakatan. Dalam Community Based Tourism (CBT), pengembangan wisata akan memberikan kesempatan kepada masyarakat lokal untuk mengontrol dan terlibat langsung dalam pengelolaan dan pembangunan objek wisatanya. Selain itu, masyarakat yang tidak terlibat langsung dalam usaha pariwisata juga bisa mendapatkan keuntungan sehingga terjadi pemerataan keuntungan yang adil bagi semua anggota masyarakat yang terkena dampat pariwisata secara langsung maupun tak langsung (Brahmanto, 2018).

Partisipasi masyarakat dalam pembangunan pariwisata khususnya dalam pengelolaannya dapat memanfaatkan dan memperbaiki kesempatan pada kualitas hidupnya. Partisipasi merupakan peran serta dalam pengelolaan objek wisata baik dalam prosesnya, dalam bentuk kegiatan, serta dapat memanfaatkan objek wisata yang dapat dinikmati oleh masyarakat. Pelaku partisipasi bergantung pada peran sertanya dalam proses pembangunan yang tergantung pada tingkat kemampuan dan kesempatan sesorang untuk ikut berpartisipasi dalam proses pembangunan pariwisata tersebut (Riskayana, 2012:181).

Pada tujuannya partisipasi masyarakat dapat menghasilkan persepsi dan ide-ide yang dapat berguna untuk masyarakat yang berkepentingan dengan meningkatkan kualitas pengambilan keputusan (Santoso dalam Riskayana, 2012), karena dengan melibatkan masyarakat yang berpotensi terkena dampak dari kegiatan dengan, engambil keputusan, kebutuhan dan pengharapan kelompok masyarakat, dan kelompok masyarakat tersebut menuangkannya dalam suatu konsep. Reaksi dan pandangan masyarakat akan membantu mereka sendiri dalam hal seperti pengambilan keputusan untuk menentukan kepentingan atau prioritas dan arah yang lebih positif dari berbagai macam faktor.

Tebing Koja ini awalnya adalah pertambangan pasir dan kapur milik pribadi Jaenudin. Lokasinya berdekatan dengan persawahan di sebuah perdesaan dan memiliki bentukkan tebing yang unik maka banyaknya orang yang datang, kemudian masyarakat desa Cikuya dan seorang fotografer berinisiatif memberikan sarannya kepada pemilik objek tersebut untuk dijadikan tempat wisata. Setelah objek penambangan ini dijadikan tempat wisata kemudian partisipasi masyarakat 
terhadap objek wisata tersebut banyak diminati, banyaknya masyarakat yang ikut berpartisipasi pada pengelolaan objek wisata Tebing Koja. Namun, masyarakat yang berpartisipasi tersebut hanyalah masyarakat yang tinggal disekitaran Tebing Koja. Masyarakat lain maupun masyarakat Desa Cikuya masih acuh tak acuh terhadap adanya objek wisata Tebing Koja yang dapat memberikan keuntungan dalam perekonomian mereka. Kemudian terdapatnya kelompok masyarakat yang melakukan keuntungan sendiri tanpa berpartisipasi dalam pengelolaan Tebing Koja nya. Sehingga berdasarkan penjelasan tersebut partisipasi yang sudah dilakukan masyarakat terhadap pengelolaan Tebing Koja sangatlah masih kurang, terlihat dari kurang terawatnya sarana dan prasarana yang ada di Tebing Koja. Hal tersebut dikarenakan kurang sesuainya tujuan antara pemilik Tebing Koja dengan harapan dari masyarakat tersebut, sehingga pengelolaan pada Tebing Koja menjadi tidak optimal. Padahal Tebing Koja ini dapat dijadikan sumber pendapatan mereka untuk meningkatkan perekonomian mereka sendiri.

Dilihat dari daya tarik wisatanya, Tebing Koja ini memiliki daya tarik wisata yang sangat menarik untuk mendatangkan para wisatawan di Kabupaten Tangerang maupun daerah lainnya. Kemudian dapat menambah peluang bisnis bagi masyarakat sekitar Tebing Koja seperti membuka usaha kerajinan khas daerah tersebut. Dengan begitu dapat meningkatkan pendapatan perekonomian bagi masyarakat itu sendiri maupun masyarakat Desa Cikuya.

Oleh karena itu berdasarkan penjelasan di atas, maka peneliti tertarik untuk melakukan penelitian mengenai "Rencana Pengelolaan Partisipatif Objek Geowisata Tebing Koja (Studi Kasus: Tebing Koja, Desa Cikuya, Kecamatan Solear, Kabupaten Tangerang”.

\section{Rumusan Permasalahan}

Objek wisata yang dijadikan daya tarik utamanya adalah tebing yang unik hasil penambangan sudah menjadi tempat tujuan wisata utama Kabupaten Tangerang. Namun, belum terdapatnya pengelolaan yang terstruktur dan yang mengikuti sistem dari prinsip pariwisata berkelanjutan, yaitu dengan pengelolaan yang berbentuk partisipatif yang dapat melibatkan masyarakat lokal sepenuhnya dalam proses kegiatannya karena masyarakat Desa Cikuya belm terlibat sepenuhnya dalam pengelolaan objek wisata tersebut. Karena objek wisata Tebing Koja masih dapat berpotensi untuk dikembangkan dan dikelola lebih optimal lagi dan tentunya dapat menjadikan wisata yang berkelanjutan

\section{Tujuan}

Pada penelitian ini bertujuan untuk menjabarkan bentuk partisipasi pada pengelolaan objek wisata Tebing Koja agar menjadikan pariwisata yang berkelanjutan, dengan sasaran berupa : (1) peran masyarakat dalam partisipasi pengelolaan objek wisata Tebing Koja; (2) konsep pengelolaan pariwisata berbasis masyarakat atau CBT (Community Based Tourism) ; (3) faktor yang menjadi penghambat dalam pengelolaan objek wisata Tebing Koja.

\section{KAJIAN LITERATUR}

\section{Geowisata}

Menurut Hermawan (2016), Geowisata (Geotourism) berasal dari kata "geo" yang artinya bumi dan "tourism" yang artinya wisata. Geowisata merupakan suatu jenis pariwisata berkelanjutan dan bersifat konservasi berkaitan dengan jenis-jenis sumber daya alam (bentuk bentang alam, batuan/fosil, struktur geologi, dan sejarah kebumian) suatu wilayah dalam rangka mengembangkan wawasan dan pemahaman proses fenomena yang terjadi di alam. 


\section{Pariwisata Berkelanjutan}

Menurut Burns dan Holder (dalam Fitra dan Leksmono, 2001) pariwisata berkelanjutan merupakan suatu konsep pariwisata yang dicita-citakan oleh masyarakat yang memahami pentingnya arti kerberlanjutan itu sendiri, yang menekankan pada keberlanjutan pariwisata pada tiga aspek, yaitu ekologi, sosial budaya, dan ekonomi. Oleh sebab itu, dibutuhkannya strategis perencanaan yang baik dan terpadu oleh semua stakeholder dalam pelaksanaannya.

\section{Pariwisata Berbasis Masyarakat / CBT}

Menurut Hary (2016) model tata pengelolaan yang cocok untuk geowisata dengan mengadopsi pariwisata berbasis kerakyatan/ masyarakat, atau dikenal dengan Community Based Tourism (CBT). Dalam CBT, pariwisata diinisiasi bersama masyarakat lokal, dikembangkan oleh masyarakat lokal, dan benefit dari pariwisata diharapkan dapat dinikmati masyarakat lokal sendiri ("Kyrgyz Community Based Tourism," n.d., diakses tanggal 15 Agustus 2016); (ASEAN Community Based Tourism Standart 2016). Konsep ini juga penting dalam pariwisata berkelanjutan, yaitu bagaimana masyarakat lokal dapat diberdayakan dan diikut sertakan dalam aktivitas kegiatan pariwisata itu sendiri dalam rangka memperoleh kemanfaatan dari kegiatan pariwisata. Menurun Yaman dan Mohd (2004) untuk menciptakan pembangunan pariwisata secara berkelanjutan berkaitan dengan adanya pariwisata berbasis masyarakat/komunitas atau CBT sebagai prinsip pokok dalam strategi pengelolaannya, sebagai berikut: (1) Partisipasi Maysarakat Lokal; (2) Pembentukkan Kelembagaan Desa Wisata; (3) Pengelolaan Daya Tarik Wisata berbasis Lingkungan; dan (4) Terciptanya Kegiatan Usaha Masyarakat. Menurut UNEP dan WTO (2005), terdapat 10 prinsip dasar CBT/Community Based Tourism yang digunakan sebagai tool of community development bagi masyarakat lokal: (1) Mengakui, mendukung, dan mengembangkan kepemilikan dalam pariwisata; (2) Mengikutsertakan anggota masyarakat dalam memulai setiap aspek; (3) Mengembangkan kebanggaan masyarakat; (4) Mengembangkan kualitas hidup; (5) Menjamin keberlanjutan lingkungan; (6) Mempertahankan keunikan karakter budaya lokal; (7) Membantu bekermbangnya pembelajaran tentang pertukaran budaya; (8) Menghargai perbedaan budaya dan martabat manusia; (9) Mendistribusikan keuntungan secara adil; dan (10) Berperan dalam menentukan persentase pendapatan.

\section{Partisipasi Pariwisata}

Pengembangan pada suatu pariwisata tentunya tidak dapat dipisahkan dengan partisipasi. Menurut Manafic (2003) menyatakan bahwa masyarakat tidak lagi ditempatkan sebagai seseorang yang hanya menerima apa yang diputuskan dari pemerintah, tetapi masyarakat pada saat ini juga harus dilibatkan sebagai subjek dalam kerangka mengembangkan pariwisata. Menurut Rahardjo (dalam Riskayana, 2012:182) memaparkan bahwa partisipasi dapat diartikan sebagai upaya peran masyarakat dalam suatu kegiatan yang baik dalam bentuk pernyataan ataupun kegiatan. Kemudian lanjutnya partisipasi merupakan keikutsertaan masyarakat dalam program pembangunan. Karena pada dasarnya partisipasi dapat dibedakan menjadi dua, partisipasi dengan keikutsertaan dan berperan serta atas dasar kesadaran sendiri dan kemauan sendiri tanpa adanya dorongan, dan partisipasi dengan keikutsertaan dan berperan serta atas dasar pengaruh dari orang lain atau adanya ajakan dari seseorang. Menurut Satropoetro (dalam Gabby, 2019:4), mengemukakan terdapat tiga unsur penting partisipasi yang harus diperhatikan dalam melaksanakan pengelolaan, yaitu: (1) Sumbangan dalam pemberian ide/gagasan dan tenaga ataupun keterampilan; (2) Tanggungjawab dalam menentukan kebutuhan yang diinginkan; dan (3) Evaluasi untuk menunjukan dan mewujudkan tujuan dan prioritas. Menurut Angell (dalam Gabby, 2019:5) mengatakan bahwa partisipasi yang tumbuh dapat dipengaruhi oleh banyak faktor dalam masyarakat. Berikut adalah faktor yang dapat mempengaruhi 
kecenderungan pada masyarakat dalam berpartisipasi, yaitu: (1) Pola Pikir Masyarakat; (2) Usia; (3) Pendidikan; dan (4) Pekerjaan dan Penghasilan.

\section{METODE}

Penelitian ini menggunakan pendekatan kualitatif dengan metode deskriptif analisis yang menggunakan pendeksripsian partisipatif dalam pengelolaan objek wisata Tebing Koja untuk menjadikan pariwisata yang berkelanjutan.

Lokasi penelitian difokuskan di satu objek wisata, yaitu objek wisata Tebing Koja yang terletak di Desa Cikuya, Kecamatan Solear, Kabupaten Tangerang. Objek pada penelitian ini adalah Objek Wisata Tebing Koja. Luas yang saat ini dijadikan objek wisata Tebing Koja adalah $\pm 3,4$ Ha. Batas lokasi objek wisata Tebing Koja, adalah: (1) Sebelah Barat: Kabupaten Lebak dan Serang; (2) Sebelah Utara: Desa Cikarao; (3) Sebelah Timur: Desa Cileles, Kecamatan Tigaraksa; dan (4) Sebelah Selatan: Desa Cikasungka dan Kabupaten Bogor.

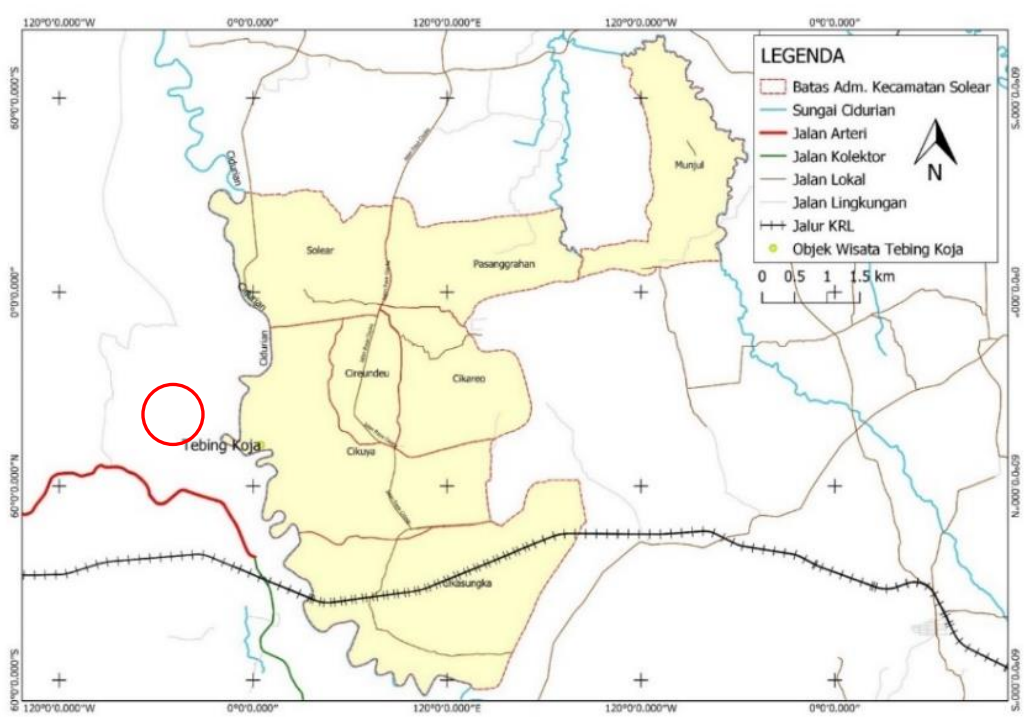

Gambar 1. Letak Lokasi terhadap Kabupaten Tangerang Sumber: Hasil Olahan Penulis dan Bappeda Kabupaten Tangerang, 2019

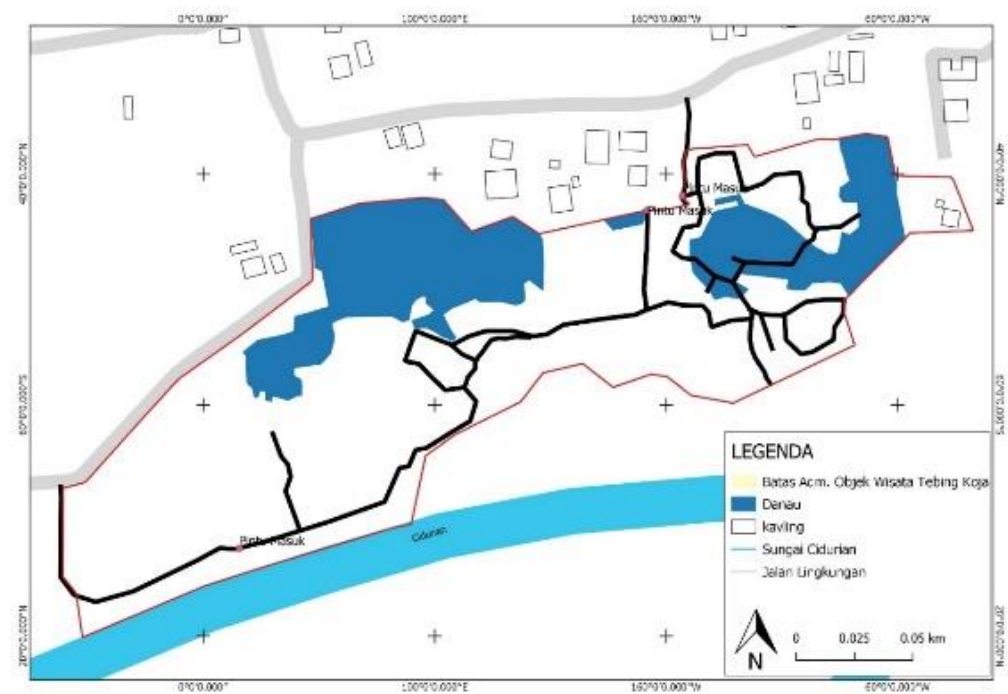

Gambar 2. Batas deliniasi Objek Wisata Tebing Koja Sumber: Hasil Olahan Penulis melalui QGis, 2019 
Teknik pengumpulan data pada penelitian kualitatif dilakukan dengan cara berupa: a) Observasi Lapangan, b) In-depht Interview, dan c) Dokumentasi. Dalam menentukkan informan, penulis menggunakan metode purposive sampling untuk mendapatkan informan/narasumber. Informan yang ada pada penelitian, meliputi: (1) Pak Jaenudin sebagai Pemilik Lahan Tebing Koja dan merupakan Pengelola dari objek wisata Tebing Koja; (2) Pak Pandil sebagai ketua RT di Kp. Koja dan merupakan salah satu Pengelola dari objek wisata Tebing Koja; (3) Pak Saed sebagai Sekretaris Desa Cikuya; (4) Ibu Tutut Murtasyiah sebagai Kepala Seksi Bidang Pariwisata Disporabudpar Kabupaten Tangerang; (5) Ibu Kokom Komariah sebagai Pedagang Warung Makanan; (6) Bapak Heru sebagai Pengelola Tebing Koja.

\section{DISKUSI DAN HASIL}

\section{Peran Masyarakat dalam Objek Wisata Tebing Koja}

Masyarakat di sekitaran Tebing Koja atau masyarakat Desa Cikuya merupakan masyarakat yang dari dahulunya lahir dan tinggal di tempat tersebut, pencaharian mereka adalah sebagai besar petani. Namun, tradisi oleh manusia dapat di ubah, tradisi dapat dikombinasikan dengan semua aktivitas manusia yang beragam (Koencaraningrat dalam Rahardjo, 2019:31). Karena dalam pengembangan pariwisata tentunya tidak dapat dipisahkan dengan partisipasi. Menurut Rahardjo (dalam Riskayana, 2012:182) partisipasi berupa keikutsertaan masyarakat dalam program pembangunan. Karena pada dasarnya partisipasi dapat dibedakan menjadi dua, partisipasi dengan keikutsertaan dan berperan serta atas dasar kesadaran sendiri dan kemauan sendiri tanpa adanya dorongan, dan partisipasi dengan keikutsertaan dan berperan serta atas dasar pengaruh dari orang lain atau adanya ajakan dari seseorang.

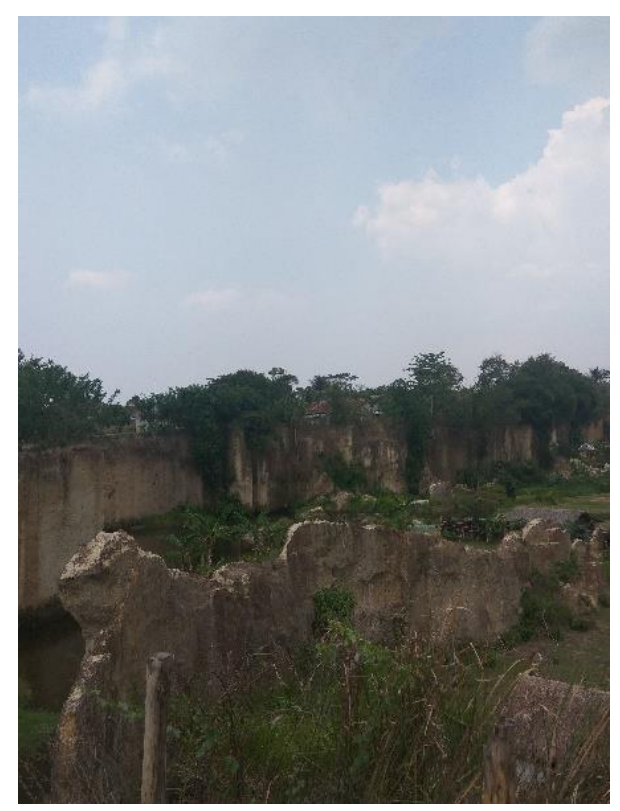

Gambar 3. Tebing berbentuk Kepala Godzilla Sumber: Dokumentasi Pribadi, 2019

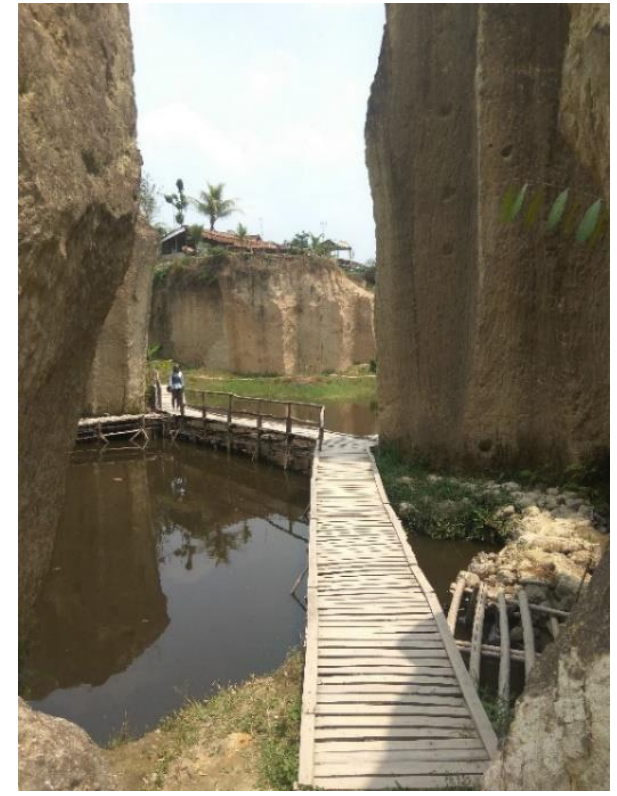

Gambar 4. Jembatan Kayu di Tebing Koja Sumber: Dokumentasi Pribadi, 2019

Pada pengembangannya, masyarakat di sekitaran Tebing Koja cukup aktif terlibat dalam proses kegiatannya, antara lain sebagai karyawan pengelola Tebing Koja yang membantu untuk menjaga dan memelihara lingkungan wisata Tebing Koja, mereka juga melakukan pemeliharan pada sarana dan prasarana kemudian tempat spot foto jika mengalami kerusakan mereka perbaiki, partisipasi lainnya yang dilakukan masyarakat Tebing Koja adalah menjadi penjaga parkir pada objek wisata, kemudian adanya juga yang sebagai pemandu atau pendamping wisatawan yang akan diajak berkeliling menelusuri semua area Tebing Koja dan mereka juga menerima jasa untuk mengambilkan foto pengunjung di tempat yang memiliki angle bagus. Hal 
tersebut berdasarkan hasil wawancara dengan Pak Jaenudin yang merupakan pemilik Tebing Koja.

Bentuk partisipasi masyarakat lainnya yang sangat banyak dilakukan oleh masyarakat sekitar lingkungan Tebing Koja adalah sebagai pedagang di warung-warung makanan yang mereka buka. Salah satu penduduk yang merupakan pedagang mie ayam dan bakso yaitu lbu Kokom, menurut hasil wawancara beliau, objek wisata ini sebagai keuntungan untuk membantu perekonomian mereka sehari hari dikarenakan sebelum adanya Tebing Koja pedagang tersebut hanyalah ibu rumah tangga tanpa memiliki usaha untuk mendorong perekonomian mereka. Mereka memanfaatkan Tebing Koja ini sebagai lahan pendapatan mereka, dengan diberikan izin oleh pemilik untuk membuka warung makan sebagai bagian pendukung dari objek wisata. Kuntungan mereka diperoleh dengan seminggu bisa mendapatkan kurang lebih 1,5 juta tanpa membayar sewa warung kepada pemilik objek wisata, artinya dalam seminggu mereka bisa mendapatkan hasil bersih 1,5 juta untuk dijadikan pendapatan mereka sebagai pedagang warung makanan.

Partisipasi yang dilakukan terkait langsung dengan konservasi lingkungan Tebing Koja, yaitu kegiatan dengan bercocok tanaman pada beberapa lahan yang dijaga area konservasinya dengan menanam berbagai jenis bunga. Kegiatan ini dilakukan oleh masyarakat sekitar, salah satunya adalah Bapak Heru yang juga salah satu pengelola, biasanya mereka menanam bunga dengan melihat kondisi area yang dapat ditanam bunga.

Salah satu yang menjadi kelemahan wisata Tebing Koja adalah keamanan yang masih minim perlu diperhatikan pada pengelolaannya. Keamanaan yang dilakukan hanya oleh pemilik objek wisata yang memantau keadaan sekitar saat Tebing Koja buka. Kegiatan partisipasi yang saat ini dibutuhkan objek wisata adalah sebagai penjaga keamanan objek wisata Tebing Koja. Dikarenakan batuan pada Tebing Koja yang mudah rapuh yang dapat membahayakan para pengunjung saat menaiki batuan tersebut, karena tidak adanya petugas yang berjaga-jaga di area batuan yang boleh dinaiki tersebut. Hal ini juga disetujui oleh pengelola Tebing Koja Pak Heru, dengan adanya penjaga keamanan yang khusus maka pengunjung akan terhindar dari halhal yang berbahaya. Keamanan dalam pariwisata harus diperhatikan dalam segi keamanan sarana dan prasarananya dan keamanan untuk para pengunjung saat berada di Tebing Koja. Maka dari itu peningkatan keamanan juga sangat perlu dilakukan dalam pengelolaan dengan melibatkan masyarakat sekitar yang akan melakukan kegiatan tersebut demi pengunjung merasakan kenyamanan saat berada di Tebing Koja.

\section{Konsep Pengelolaan Pariwisata Berbasis Maysraakat atau CBT}

Menurut UNEP dan WTO (2005), terdapat 10 prinsip dasar CBT yang digunakan sebagai tool of community development bagi masyarakat lokal yang dijabarkan penemuan eksisting melalui wawancara dan menggunakan prinsip tersebut sesuai dengan kemampuan yang ada pada masyarakat lokal di Tebing Koja. Prinsip dasar CBT adalah menempatkan masyarakat sebagai pelaku utama diberbagai kegiatan kepariwisataan dengan melalui pemberdayaan masyarakat, sehingga manfaat yang datang dari kepariwisataan sebesar-besarnya adalah untuk masyarakat.

a. Mengakui, mendukung dan mengembangkan kepemilikan dalam pariwisata

Masyarakat lokal pada hakekatnya ditujukan untuk mendukung pengembangan pariwisata, mengakui kepemilikan pariwisata di daerahnya, dan dapat ikut berpartisipasi dalam mengembangkan pariwisata tersebut. Dengan hal tersebut masyarakat dapat membantu dalam mempromosikan Tebing Koja, misalkan salah satunya ke dalam media sosial dengan mengiklankan Tebing Koja dapat bekerja sama dengan fotografer yang berlangganan dengan tempat Tebing Koja. Secara tidak langsung dengan begitu masyarakat di Desa Cikuya dapat merasa bangga dengan kepemilikan objek wisata yang mereka punya di 
daerah mereka tinggal.

b. Mengikutsertakan anggota masyarakat dalam memulai setiap aspek

Tebing Koja merupakan objek wisata yang dapat melibatkan seluruh masyarakat dalam pengembangan objek wisata tersebut baik secara langsung maupun tidak langsung. Dalam wawancara dengan tokoh masyarakat juga mengaharapkan masyarakat dapat lebih terlibat langsung dalam setiap kegiatan pariwisata di Tebing Koja. Sebagian masyarakat Desa Cikuya memang menginginkan pariwisata bisa berkembang dengan lebih baik lagi agar usaha yang telah dilakukan dalam setiap kegiatan pariwisata sekarang bisa terus berlanjut. Berpartisipasi yang dilakukan secara langsung sebagai pekerja dan pengelola objek wisata dapat mendatangkan keuntungan ekonomi secara langsung bagi masyarakat lokal. Selain berkaitan dengan ekonomi, itu masyarakat lokal juga dapat terlibat dalam social seperti evaluasi mengenai keberlanjutan objek wisata yang dilakukan oleh pemilik dan pengelola. Karena pendapat masyarakat juga penting bagi keberlanjutan objek wisata. Dengan mengadakan rapat musyawarah dengan masyarakat lokal dan menampung setiap pemikiran yang dikemukakan oleh masyarakat, kemudian hasilnya dapat disetujui secara bersama-sama.

c. Mengembangkan kebanggaan masyarakat

Dapat dilihat dari dengan adanya Tebing Koja masyarakat dapat menyadari bahwa objek wisata Tebing Koja memiliki keunikan tersendiri dengan segala potensi dan daya tarik wisatanya sehingga masyarakat dapat menciptakan peluang bisnis pariwisata, seperti yang ditemukan dari hasil observasi lapangan banyaknya masyarakat yang membuka warung kecil dan warung makan, membuka lahan rumahnya menjadi lahan parkir, menjadi pemandu wisata, dan menjadi jasa pengambilan foto. Dengan adanya keunikan pada bentukkan tebing menjadikan Tebing Koja mudah dikenal oleh masyarakat luar dan mudah dikenal wisatawan karena bentukkan tebing-tebing yang unik menjadi pertama kali yang ada di Desa Cikuya, Kecamatan Solear dibanding tempat lainnya. Dengan adanya kebanggaan ini maka dengan dapat sendirinya masyarakat untuk melestarikan alam untuk keberlanjutan pariwisata di Tebing Koja.

d. Mengembangkan kualitas hidup

Berlanjut dari kebanggaan komunitas dapat muncul atau menciptakan peluang bisnis yang tidak hanya warung, pemandu wisata, dan penyedia tempat parkir. Karena dengan menciptakan peluang bisnis dapat mengembangkan kualitas hidup masyarakat lokal dengan pendapatan yang diperoleh oleh setiap masyarakat dapat bertambah. Karena kualitas hidup yang baik juga diperoleh karena masyarakat lokal telah menerima penghasilan dari pariwisata yang masuk di Tebing Koja. Keuntungan ekonomi yang diperoleh masyarakat dari masyarakat sekitar Tebing Koja tentunya akan berdampak pada meningkatnya standar hidup baik dari segi kesehatan, tingkat pendidikan. Maka dari itu masyarakat lokal dapat mengembangkan kualitas hidup dengan membuka sejumlah usaha, seperti homestay untuk wisatawan yang berlasal dari luar Kabupaten Tangerang karena salah satu daya tarik Tebing Koja adalah melihat fenomena sunset dan sunrise. Kemudian masyarakat lokal dapat membuat paket tour ke objek wisata lainnya yang terdekat dengan Tebing Koja. Sehingga pendapatan yang diperoleh oleh masyarakat lokal dari bekerja tersebut dapat dipergunakan untuk keperluan sehari-hari atau keperluan lainnya seperti untuk menyekolahkan anak.

e. Menjamin keberlanjutan lingkungan

Tebing Koja bersama masyarakat lokal dapat memanfaatkan menjaga kelestarian lingkungan dengan menjaga kebersihan dan memperhatikan masalah persampahan dengan menambah titik area tempat sampah, tidak mengeksploitasi lingkungan secara berlebihan, menanam tanaman atau tumbuhan pada area konservasi, menjaga area konservasi tetap kosong dari bangunan warung-warung. Menjaga kelestarian lingkungan pada objek wisata ini mucul karena merupakan objek wisata bekas tambang. Berdasarkan 
hasil wawancara dengan pemilik objek wisata, masyarakat lokal yang ikut berpartisipasi dalam pengelolaan sudah mendapatkan himbauan untuk selalu menjaga kelestarian lingkungan dan pemerintah daerah juga sudah memberikan himbauan akan pentingnya menjaga lingkungan dalam area objek wisata.

f. Mempertahankan keunikan karakter dan budaya lokal

Tebing Koja dapat memanfaatkan dan mengembangkan potensi yang ada dengan bekerja sama dengan komunitas topi bambu dan melibatkan masyarakat lokal untuk membuat kerajinan khas bambu dengan hasil karya berupa topi, tas, dompet, dan lain-lain. Masyarakat yang akan berpartisipasi dapat dibina terlebih dahulu untuk memahami bagaimana pembuatan kerajian khas dari bambu tersebut. Kerna komunitas kerajinan bambu tersebut juga memiliki tempat pelatihan untuk membuat kerajinan sebelum masyarakat mengerjakan kerajinan bambu dengan skala lebih banyak.

g. Membantu berkembangnya pembelajaran tentang pertukaran budaya

Berdasarkan hasil wawancara dengan pemilik objek wisata, yaitu Pak Jaenudin dan penemuan saat observasi pertukaran budaya belum muncul dikarenakan tidak adanya atraksi budaya yang ditampilkan kepada pengunjung baik pergelaran seni, maupun hasil karya yang khas yang dapat membuat mereka penasaran dan ingin mengetahuinya. Namun, hal tersebut dapat dimaklumi karena Tebing Koja yang menawarkan destinasi wisata alam. Maka dari itu, dengan adanya kerjasama dengan komunitas topi bambu dengan adanya masyarakat yang menghasilkan kerajinan topi bambu tersebut dapat menjadikan pengembangan pembelajaran mengenai pertukaran budaya, agar masyarakat yang dari luar Kabupaten Tangerang dapat mengetahui bahwa adanya kerajinan topi bambu tersebut dan jika topi bambu membuka cabang pusat kerajinan di Tebing Koja maka wisatawan dapat ikut belajar dalam hal membuat kerajinan tersebut. Kemudian kegiatan tersebut dapat menambah daya tarik dari Tebing Koja itu sendiri.

h. Menghargai perbedaan budaya dan martabat manusia

Berdasarkan hasil observasi lapangan yang dilakukan peneliti, ditemukan bahwa umumnya masyarakat setempat di Tebing Koja sangat ramah dalam menyambut pengunjung sehingga upaya untuk menghormati budaya yang berbeda suda hada dilakukan dengan semaksimal mungkin. Hal ini bisa dilihat ketika ada pengunjung maka beberapa masyarakat masih langsung memberi senyum kepada pengunjung tersebut, pengunjung juga menerima sambutan dari pengelola sehingga sudah terlihat kesan dalam penghargaan terhadap budaya yang berbeda secara maksimal.

i. Mendistribusikan keuntungan secara adil

Pendapatan yang diperoleh dari objek wisata Tebing Koja secara keseluruhan berasal dari karcis parkir kendaraan, tiket masuk pengunjung, penyewaan untuk pre-wedding atau perekaman video, penyewaan perahu kayu, dan penyewaan objek foto. Dari semua sumber pemasukan tersebut, penghasilannya masuk kedalam pemilik dan dibagi kepada 10 orang pengelola Tebing Koja dan sebagian disumbangkan kepada mushollah di Desa Cikuya. Kecuali untuk para pedagang atau yang memiliki warung makan, pemasukkannya dimiliki oleh penjual. Dari hal tersbut dapat terlihat bahwa masih belom adanya pembangian pendapatan yang secara adil. Dikarenakan dalam teorinya pembagian keuntungan yang adil dengan keuntungan yang diterima oleh masyarakat secara langsung yang memilki usaha disektor pariwisata tetapi keuntungan tidak langsung yang diterima dan dinikmati masyarakat dari kegiatan pariwisata dapat lebih luas anatara lain berupa proyek pembangunan yang dibiayai dari hasil penerimaan pariwisata (Yaman dan Mohd, 2004). Kemudian masyarakat setempat dalam wawancaranya juga berharap dengan partisipasi yang dilakukan masyarakat maka pemilik dapat membagi keuntungan secara adil kepada masyarakat yang ikut berpartisipasi dalam proses kegiatan wisata tersebut. Pemilik objek wisata pun mengaku bahwa kesulitan dalam membagikan pendapatan secara merata dan adil kepada masyarakat yang terlibat dalam pengelolaan Tebing Koja. Maka diperlukannya 
organisasi/kelompok yang terpercaya untuk mengelola keungan dari hasil keuntungan pada objek wisata agar lebih dapat terkelola dengan baik perputaran pembagian keuntungannya. Kemudian keuntungan tersebut dapat dibagi untuk desa, pengelolaan, pengembangan, gaji karyawan, dan dana social.

j. Berperan dalam menentukan presentase pendapatan

Berdasarkan hasil wawancara dengan pengelola, yaitu Pak Heru, pemilik saat ini yang berperan dalam menentukan persentase pendapatan. Namun hal ini seharusnya juga dapat melibatkan masyarakat setempat yang ikut berpartisipasi dalam pembahasan mengenai penentuan persentase pendapatan. Dengan seperti yang sudah dibahas sebelumnya dengan melakukan rapat secara musyawarah kemudian hasil rapat tersebut didapatkan berdasarkan persetujuan secara bersama antara pemilik/pengelola dan masyarakat. Karena masyarakat lokal juga dapat berhak dalam peran menentukan persentase pendapatan yang ada.

\section{Faktor Penghambat}

a. Belum terbentuknya organisasi/kelompok sadar wisata

Berdasarkan hasil penelitian Tebing Koja tidak memiliki organisasi seperti BUMDes dan pokdarwis yang dapat membantu dalam pengelolaan wisata. Karena dengan adanya pokdarwis dapat membantu masyarakat sekitar yang ingin berpartisipasi dalam pengelolaan objek wisata dan diberi pembekalan secara siap untuk. Kemudian BUMDes sendiri dapat membantu dalam mengelakukan pengaliran keungan dan pembagian keuntungan yang adil dalam penanganan pendapatan pengelolaan objek wisatanya. Dalam teori Brahmanto (2018) suatu pembangunan kepariwisataan tidak bisa lepas dari sumber daya dan komunitas lokal.

b. Pola Pikir Masyarakat

Pola pikir yang dimiliki oleh beberapa masyarakat berbeda dengan pengelola dan pemilik Tebing Koja. Karena itu maka merupakan menjadi slaah satu faktor penghambat dalam pengelolaan objek wisata. Dalam teorinya menurut Anggle (dalam Gabby, 2019) pola pikir ini merupakan salah satu faktor yang memang dapat mempengaruhi kecenderungan masyarakat dalam berpartisipasi, jika tidak memiliki pola pikir yang sejalan maka pengelolaan tidak akan berjalan dengan optimal.

c. Pendidikan

Masyarakat Desa Cikuya menurut data Desa pendidikan terakhir mereka adalah SMA dan sedikit SMP. Kemudian pendidikan mereka mengenai kepariwisataan dan keterampilan juga masih minim. Oleh karena itu, banyak masyarakat yang tidak mengetahui apa-apa mengenai wisata Tebing Koja. Mereka yang ikut berpartisipasi tetap ikut namun tidak adanya bimbingan dan penjelasan mengenai wawasan dalam berpengelolaan objek wisata. Dalam teorinya pun pendidikan juga merupakan faktor yang sangat mutlak dapat mempengaruhi kecenderungan masyarakat dalam berpartisipasi. Sehingga mereka yang memiliki pengetahuan sangat minim tidak ingin ikut berpartisipasi dalam proses pengelolaan objek wisata tebing Koja.

\section{KESIMPULAN DAN SARAN}

\section{Kesimpulan}

Peran masyarakat dalam ikut serta berpartisipasi dalam pengelolaan Tebing Koja, cukup aktif dengan ikut beberapa kegiatan yang terkait langsung dalam pengelolaan objek wisata, seperti sebagai karyawan pengelola yang menjaga dan memelihara lingkungan Tebing Koja, membuka usaha warung makanan, membuka usaha tempat parkir, dan sebagai pemandu wisata yang juga menawarkan jasanya sebagai juru kamera. Masih terdapat kegiatan yang perlu partisipasi masyarakat di Tebing Koja.

Objek wisata Tebing Koja dapat menerapkan prinsip-prinsip dasar yang ada pada konsep 
pengelolaan pariwisata berbasis masyarakat atau CBT berupa 10 unsur yang dapat digunakan sebagai usulan konsep dengan menyesuaikannya terhadap kondisi lingkungan yang ada sekarang pada lingkungan objek wisata Tebing Koja, yaitu: (1) Mengakui, mendukung, dan mengembangkan kepemilikan dalam pariwisata; (2) Mengikutsertakan anggota masyarakat dalam memulai setiap aspek; (3) Mengembangkan kebanggaan masyarakat; (4) Mengembangkan kualitas hidup; (5) Menjamin keberlanjutan lingkungan; (6) Mempertahankan keunikan karakter budaya lokal; (7) Membantu bekermbangnya pembelajaran tentang pertukaran budaya; (8) Menghargai perbedaan budaya dan martabat manusia; (9) Mendistribusikan keuntungan secara adil; dan (10) Berperan dalam menentukan persentase pendapatan.

Namun, ditemukannya beberapa faktor yang menjadi penghambat dalam pengelolaan partisipatif pada objek wisata Tebing Koja, seperti belum terdapatnya atau belum terbentuknya organisasi/kelompok masyarakat yang dapat memberikan pelatihan dan wawasan terhadap masyarakat, perbedaan pola pikir masyarakat Desa Cikuya, dan keterbatasan latar belakang pendidikan masyarakat Desa Cikuya.

\section{Saran}

Terdapat beberapa program yang perlu kemungkinan untuk ditambah atau diperbaiki, seperti pemilik dan para pengelola mengadakan rapat musyawarah dengan perwakilan setiap RT di Desa Cikuya untuk membahas mengenai pembangunan pariwisata Tebing Koja agar setiap anggota masyarakat dapat membantu dalam setiap aspek pengembangan maupun pengelolaan wisata. Kemudian adanya pembentukan organisasi/kelompok sadar wisata oleh Pemerintah Daerah khususnya Disporabudpar Kabupaten Tangerang dan Pemerintah Desa Cikuya yang dapat memberikan pelatihan terhadap masyarakat sekitar Tebing Koja agar masyarakat tersebut juga mendapatkan pengetahuan mengenai pengembangan dan pengelolaan objek wisata agar dapat berjalan dengan baik dan dapat menambah masyarakat untuk ikut berpartisipasi dalam pengelolaan tersebut. Masyarakat Desa Cikuya bekerjasama dengan komunitas kerajinan bambu lokal untuk pelatihan dalam membuat kerajinan yang nantinya akan dijadikan souvenir. hal tersebut juga dapat meningkatkan kualitas dari masyarakat sekitar Tebing Koja agar kedepannya dapat terus berlanjut. Membangun pos keamanan dan pusat informasi dan menambahkan titik-titik tempat sampah yang melibatkan banyak masyarakat sekitar Tebing Koja atau masyarakat Desa Cikuya dan kemudian membuat struktur mengenai pengelolaan Tebing Koja secara lebih jelas agar adanya penanggung jawab dalam setiap aspek dalam pengelolaan di objek wisata Tebing Koja.

\section{REFERENSI}

Adisasmita, R. (2006). Pembangunan Pedesaan dan Perkotaaan. (pp. 38). Yogyakarta: Graha Ilmu.

Blezeszeinsky, G. (2019). Partisipasi Masyarakat Dalam Pelestarian Lingkungan di Kawasan Pantai Padang. Journal of Education on Social Science, 4(1), 3-6.

Gani, Y.A. (2017). Pengembangan Sarana Prasarana Destinasi Pariwisata Berbasis Budaya di Jawa Barat. Jurnal Pariwisata, 4(1), 24-25.

Hermawan, H. (2016). Dampak Pengembangan Desa Wisata Nglanggeran Terhadap Ekonomi Masyarakat Lokal. Jurnal Pariwisata, 3(2), 105-117.

Hermawan, H. (2018). Geowisata: Solusi Pemanfaatan Kekayaan Geologi Yang Berwawasan Lingkungan. Jurnal Sains Terapan Pariwisata.

Hermawan, H dan Brahmanto, E. (2018). GEOWISATA: Perencanaan Pariwisata Berbasis Konservasi. (pp. 57-60). Jawa Tengah: PT Nasya Expanding Management.

Hamidah, N. (2016). Skripsi: Partisipasi Masyarakat dalam Pengelolaan Objek Wisata (Studi Kasus Objek Wisata Bukit Jamur di Kecamatan Bungah Gresik). Universitas Negeri Surabaya. 
Rahardjo, P., \& Nuzzela, S. (2019) Studi Pengembangan Ekowisata di Pulau Kecil (Kasus Pulau Pramuka di Provinsi Jakarta). Penelitian Universitas Tarumanagara.

Riskayana. (2012). Partisipasi Masyarakat dalam Pengelolaan Objek Wisata Alam Pantai Karsut di Desa Kampala Kecamatan Arungkeke Kabupaten Jeneponto. Jurnal Ilmu Pemerintahan, 2(2), 182-189. 